Total Expenditure and Total Revende of the United Kingdom and the Relation Between the Two in Each Fiscal Year from 1914 to 1921

\begin{tabular}{|c|c|c|c|}
\hline Year Ended March 31 & $\begin{array}{c}\text { Total } \\
\text { Expenditure }\end{array}$ & $\begin{array}{c}\text { Total } \\
\text { Revenue }\end{array}$ & $\begin{array}{l}\text { Relation of } \\
\text { Revenue to } \\
\text { Expenditure }\end{array}$ \\
\hline 1914 (pre-war). & $£ 197,000,000$ & $£ 198,000,000$ & $\begin{array}{c}\text { Per cent } \\
100.5\end{array}$ \\
\hline $1915 \ldots \ldots$ & $561,000,000$ & $227,000,000$ & 40.4 \\
\hline $1916 \ldots \ldots \ldots$ & $1,559,000,000$ & $337,000,000$ & 21.6 \\
\hline $1917 \ldots \ldots \ldots$ & $2,198,000,000$ & $573,000,000$ & 26.1 \\
\hline $1918 \ldots \ldots \ldots$ & $2,696,000,000$ & $707,000,000$ & 26.2 \\
\hline 1919. & $q, 579,000,000$ & $889,000,000$ & 34.5 \\
\hline $1920 \ldots$ & $1,666,000,000$ & $1,340,000,000$ & 80.4 \\
\hline $1921 \ldots$ & $1,195,000,000$ & $1,426,000,000$ & 119.3 \\
\hline
\end{tabular}

and the total annual revenue of the United Kingdom for each fiscal year since 1914 and the relation between the two. You will observe from that table that the revenue which stood at 198,000,000 pounds, or $\$ 990,000,000$, in 1914 grew to $1,426,000,000$ pounds, or $\$ 7,130,000,000$, in 1921. This, I think, may be regarded as a very noteworthy achievement in the circumstances.
One may also derive some encouragement from the last budget statement just made by the Chancellor of the Exchequer, in which he felt that the situation in Great Britain had so much improved that he was able to give substantial relief in connection with the income tax and a few other of the most onerous burdens borne by the British people during the last several years.

\title{
The Finance and Currency Situation in Poland
}

\author{
By E. Dana Durand \\ Bureau of Foreign and Domestic Commerce, Washington, D. C.
}

Poland, with its fiduciary curPrency inflated to more than 250 billions of marks and depreciated to approximately the thousandth part of its nominal value, is frequently held up as a classic example of bad financial management. Apart from Russia and Austria, there is no country whose currency is so depreciated. However, despite her unfortunate currency situation, Poland is making very real economic progress. One is, therefore, forced to the conclusion that there are other factors more important in determining the economic situation of a country than its currency.

The Germans, during their occupation of former Russian Poland, introduced a currency identical in nominal value with the German mark and guaranteed by the German Imperial Bank. When Poland became independent, she began issuing currency of her own, bearing the same name, but carrying the inscription: "The Polish Government assumes the re- 
sponsibility of exchanging this note for the future Polish currency at a rate to be established by the Diet."

At the outset of Poland's national life, the amount of German paper marks in circulation, together with the equivalent value of crowns, roubles and other paper money still circulating in certain parts, was in the neighborhood of 3 billion marks. By January, 1920, the amount had been increased to about 8 billions; by January, 1921, to 50 billions; by January, 1922, to 230 billions; and by April 1, 1922, to 251 billions. During 1920 , the amount outstanding increased about six-fold; during 1921, about four-fold.

Up to the end of 1921, much the greater part of the expenditures of the Polish government were met by the issue of paper money. According to a recent statement of the Finance Minister, the total expenditures from the beginning of the independent existence of Poland, toward the close of 1918 up to the end of 1921, were 324 billions (for the most part only the excess of expenditures of railways and certain other government enterprises over their receipts was included in this amount), and the revenues, 102 billions, leaving a deficit, covered by internal loans and, for the larger part, by paper money, of 222 billions, or 69 per cent of the expenditures. As more fully pointed out later, there has been a great improvement in the budget situation during recent months.

As the natural result of this great multiplication of the circulating medium in Poland, its value both within the country and in foreign exchange has fallen enormously. Prices have mounted by leaps and bounds. The normal ratio of marks (that is, German gold marks) to the dollar is approximately four. By January, 1920, it took 128 Polish marks to buy a dollar; by January, 1921, 750; and in September, following a toboggan-fall during the summer, the rate reached about 7,000 to the dollar. Since that time there has been an improvement. At present, the rate is in the neighborhood of 4,000 , or one-thousandth of the par value.

\section{Causes of Inflation}

Spectacular as has been this inflation and depreciation of the Polish currency, there was more excuse for it than many people have been inclined to allow, and, on the other hand, its effects, although serious, have been less catastrophic than many have supposed.

It would have been unreasonable to expect the new Polish State, under the extraordinary conditions which confronted it during the first two or three years of its existence, to raise sufficient taxes to cover its expenditures, and equally unreasonable to expect it to be able to borrow from its people, by ordinary unforced loans, any large sums. The country was made up of parts of three former empires, each with a different system of taxation. In each of these three empires, the policy during the War had been to meet only a small part of government expenditures by taxation, and to issue great quantities of paper money as well as great amounts of bonds. The new government inherited these divergent tax systems and this all too uniform practice of warfinanciering. Moreover, its people were impoverished by the sheer ravages of war and by the exactions of hostile armies of occupation. Agriculture, the basic industry, was so ruined that the United States had to come with relief to save the people from starvation. Moreover, Poland did not, with the Armistice of 1918, gain the blessings of peace. She was at war with 
Bolshevik Russia until September, 1920. The war was a terrible burden of expense, while it also hindered the recovery of production and the development of tax-paying capacity.

The only available recourse was the forced contribution-more truly a tax than a loan-through the issue of paper money. The process of inflation once begun tended itself to prevent a cure. Taxes could not catch up with depreciation. A tax assessed on the basis of a given scale of values and incomes and paid some months or a year later, money meanwhile having lost a large fraction of its buying power, went but a little way toward government expenditures. Only altogether extraordinary methods of taxation, such as could not be expected to be effectively enforced in so young and so impoverished a state, could have balanced the budget. As we shall see, the Polish government has at last, within the past few months, taken the bull by the horns and undertaken such Spartan measures, but it had pretty good excuse for not undertaking them earlier in its career. Moreover, by reason of the very fact that papermoney inflation had begun, the government naturally found it impossible to sell any large amount of bonds at home or abroad to cover its deficits, and had to go on with further inflation.

\section{Internal Prices and Exchange Rates}

It is interesting to compare the changes in the value of Polish currency with the changes in the amount outstanding, and to compare the changes in the internal value as measured by prices of commodities with the changes in the external value as measured by exchange. On account of the uncertainty of earlier statistics, comparison may best be based on the figures for January, 1920. At the end of March, 1922, the amount of paper money outstanding was 28.7 times greater than in that month. The level of internal prices (as measured by the cost of food at Warsaw) had multiplied meantime about 25 times. The number of marks necessary to buy a dollar in foreign exchange had multiplied 30.3 times. The parallelism in the three items is thus quite close. While there have been times when a great disparity existed between exchange rates and internal prices, at present the disparity is comparatively small. In the summer of 1921 a person with American dollars in Warsaw could dine in the best restaurants for a mere fraction of what he would have to pay in America, but at present the dollar does not go a great deal further in Poland than in our own country; or, more strictly speaking, the difference is now not much greater than before the War.

The increase in prices in Poland, representing the depreciation of the mark, although rapid, has been at a fairly even pace. This is not true, however, of the fall in exchange. This has been subject to marked fluctuations. The sharpest took place in the second half of 1921. On June 1, the rate of exchange was about 1,000 marks to the dollar. By July 1, it had fallen to more than 2,000, and by the latter part of September to around 7,000. Barely a month later it had risen to less than 2,500 to the dollar. On one day during this period the rate rose from about 6,000 to about 4,000 and fell again to about 5,000 . Since November exchange has been much steadier but it still has fluctuated more than prices.

Exchange rates are subject to influences which have very little effect upon the purchasing value of money within the country. They are decidedly affected, of course, by the balance of trade. They are influenced 
by opinion as to the general political and economic outlook of the country for both the near and the distant future. They are influenced greatly also by opinion as to the prospects regarding the balance between government expenditures and receipts and the consequent quantity of paper money likely to be issued in the future. Finally, exchange rates are often seriously affected by sheer speculation and by deliberate manipulation. Important as it is that further inflation of currency in Poland, as in other European countries, should be checked, it is almost equally important that, if inflation continues, the movements of foreign exchange should become steadier and follow more closely the movements of internal prices.

\section{Effects of Inflation}

What now have been the effects of this inflation of the currency upon economic conditions in Poland? It is obvious that the value of securities having a fixed rate of return has been virtually wiped out. That effect, however, was substantially accomplished long ago. The creditor class, as such, is almost as completely erased from the economic slate by depreciation of its claims to the fiftieth part of their value as to the thousandth part. The number of persons dependent upon fixed investments in Poland was far less, relatively, than in more highly industrialized countries, and consequently the social effect of their losses is of less significance.

More important from the practical economic standpoint has been the checking of new credit transactions. Even short-term credits involve too much risk and the great bulk of business is done on a cash basis. In a country with an intricate industrial system like the United States, the stoppage of credit would have an ex- tremely serious effect upon production and trade, but in the simpler economic life of Poland, where agriculture occupies two-thirds of the population, the effect has been much less grave.

The most important evidence to show that paper money in Poland has not been entirely destructive of internal economic progress is found in the statistics of actual production of the principal industries. In practically every industry, there has been a marked increase of output, month by month and year by year, since the Armistice, and while, in general, production has by no means yet attained the pre-war level, it seems not at all impossible that it may do so in a few years more, even if further depreciation of currency still continues.

Especially important has been the recovery in Polish agriculture. In the year following the Armistice, the crops of Poland were scarcely half of the prewar production, and America had to furnish large quantities of food for the relief of the population. The crop of 1921 was equal to three-fourths of the pre-war production. In the case of rye, the most important grain, the output in 1921 was double that in 1920 , largely owing to more favorable weather conditions, but partly owing to increase of acreage. Year by year the peasants have planted more land and reports indicate that a still further increase is being made for 1922 .

Again, the production of coal in Poland, which had been greatly reduced by the War, has been gaining steadily until at present it is substantially equal to that of 1913 , the best pre-war year. More salt is being produced than before the War. The output of forest products is rapidly increasing and the Port of Danzig is choked with lumber, its facilities for trans-shipment having proved inadequate. The cotton mills are producing at nearly 
pre-war capacity, and almost all manufacturing industries have been making rapid strides. Railroad transportation has increased greatly in volume and improved in efficiency.

The truth seems to be that business in Poland has learned to adjust itself fairly well to the abnormal currency situation. The advance in prices has become more or less standardized. Wages have followed prices with sufficient closeness to prevent serious labor disturbances. Paper money is like some diseases to which, after a time, the human system so adapts itself that, although uncomfortable, they cease to be very dangerous.

\section{Increased Foreign Trade}

Despite the fact that foreign exchange has shown such violent fluctuations, Poland has been able to do a very considerable and increasing foreign trade. The instability in the exchange value of the mark has naturally greatly lessened credit transactions in import business. But it has not prevented cash transactions. Indeed, the big cotton mills and the central agricultural syndicate have been able to buy on credit, the sums due being, of course, expressed in other than Polish currency. If from the statistics for the first two years of Poland's existence you eliminate the imports of food and other supplies furnished as a gift or on essentially philanthropic credit, and eliminate also coal from Upper Silesia, now in part annexed to Poland, you will find that there has been a marked increase in imports into Poland of the things she ought normally to import, at the same time that there has been a still more marked increase in exports. The mechanism of settlement of accounts is, after all, a mere, though important, incident. The fundamental factors in the existence of import trade are the need of imported goods and the possession of some means of payment. Certain kinds of imported goods Poland very greatly needs, and she has the means, in increasing degree, of paying for them. These means are exports, which are rapidly increasing, and, perhaps equally important, remittances of emigrants.

The decided improvement in the foreign trade situation of Poland is seen by comparing 1920 with 1921 and especially the first half of 1920 with the last half of 1921. Unfortunately only weights are available, not values. (The latter were first made public for January, 1922, when imports, including Upper Silesian coal, were about 27 billions of marks-roughly $\$ 9,000,000-$ and exports, 9 billions.)

\section{Recent Financial Improvement}

While Poland has thus been making real economic progress in spite of the tremendous inflation and depreciation of her currency, it is obviously most desirable that the printing of paper money should come to an end. The Poles themselves very generally recognize that fact. Public opinion in favor of budget-equilibrium has developed rapidly. The cabinet of Ponikowski, with Michalski as Finance Minister, which took office in October, has adopted a vigorous financial policy. Much has already been accomplished in reducing government expenditures and still further cuts are planned. The revenue from previously established taxes has, with more vigorous administration, been rapidly increased. If we assume that the net expenditures of the government are represented substantially by the income from taxes plus internal borrowings (through paper money or otherwise), then taxes in 1920 amounted to 9 per cent of net expenditures; in the first quarter of 1921 , to 11 per cent; and in the last quarter, to 37 per cent. More im- 
Increase in Foreign Trade of Poland, 1920-21

In 1,000 metric tons

\begin{tabular}{|c|c|c|c|c|}
\hline & 1920 & 1921 & $\begin{array}{c}\text { First half } \\
1920\end{array}$ & $\begin{array}{c}\text { Last half } \\
1921\end{array}$ \\
\hline All imports $\ldots \ldots \ldots \ldots \ldots \ldots \ldots$ & 3,530 & 4,841 & 1,908 & 2,371 \\
\hline 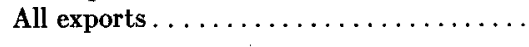 & 620 & 2,028 & 209 & 1,150 \\
\hline Excess of imports. . & 2,910 & 2,813 & 1,699 & 1,221 \\
\hline Imports except coal . & 839 & 1,316 & 423 & 639 \\
\hline Exports except coal. & 473 & 1,693 & 190 & 1,007 \\
\hline $\begin{array}{c}\text { Excess of imports.. } \\
\text { “ exports }\end{array}$ & 366 & 377 & 233 & 368 \\
\hline Exports of wood and its products ....... & 102 & 857 & 20 & 561 \\
\hline Exports of oil and its products...... & 140 & 385 & 26 & 215 \\
\hline Exports of sugar $\ldots \ldots \ldots \ldots \ldots \ldots$ & 16 & 39 & 0.3 & 12 \\
\hline Exports of cement $\ldots \ldots \ldots \ldots \ldots \ldots$ & 41 & 74 & 13 & 39 \\
\hline Imports of cotton (nearly all American) .. & 22.9 & 41.2 & 10.4 & 24.1 \\
\hline
\end{tabular}

portant still, a special "Budget Balancing Contribution" was enacted in December, to be collected during 1922 . This contribution is at rates, in most cases, several hundred times higher than those previously in force for taxes of the same class. Moreover, the government, which had met with little success in the endeavor to raise longterm internal loans, has in recent months issued in considerable sums interest-bearing treasury notes, thus lessening the need of paper-money issues.

The result of these measures has been significant. During the quarter from July to September, 1921, the amount of paper money in circulation increased 50 per cent. During the last quarter of 1921, it again increased 50 per cent. During the first quarter of 1922, the increase was only 9 per cent and during the month of March it was only $1 \frac{1}{2}$ per cent. Moreover, during the past few months, the larger part of the new paper money issued has not been due to government deficits but to loans to industry and trade.
Of the net government expenditures, calculated as above described, paper money covered in 1920,80 per cent, in the first quarter of 1921, 81 per cent, in the last quarter of 1921,51 per cent, and probably in the first quarter of 1922 (exact figures not yet available) not over 10 per cent.

\section{The 1922 Budget}

In the latter part of March, the Finance Minister submitted his budget for 1922. This contemplates expenditures, ordinary and extraordinary, of 591 billion marks. (The increase as compared with previous budgets is only apparent, being due to the greater depreciation of the currency and to other factors of incomparability.) These are gross expenditures, including the operating expenses of railways and other government enterprises. The gross revenues, including the proceeds of proposed new taxes, are put at 458 billions, with a deficit of 133 billions. The deficit, however, is due to extraordinary expenditures amounting to 151 billions, of which 112 billions 
represents investment expenditures, which the Finance Minister hopes to be able to cover by loans chiefly made abroad.

The revenue from taxes is put at about 257 billion marks, of which from ordinary direct taxes is to come 27 billions, indirect taxes, $100 \frac{1}{2}$ billions; customs, 31 billions; stamp and transfer taxes, 8 billions; and from the extraordinary budget-balancing direct taxes, 90 billions. Most of the remaining income is to come from railways and other government property.

It is, of course, uncertain whether this budget can be lived up to. Polish budgets in the past have over-estimated income and under-estimated expenditure. The present attitude of the government and of the people, however, appears to be much more firm than heretofore and, what with the increase in production and consequently in taxpaying ability, the prospects are more encouraging than at any time before.

There can be no possible doubt as to the ability of Poland to pay taxes sufficient to cover at least the ordinary expenditures of its government. This conclusion does not depend upon any statistical calculation of the income of the people and the share thereof required to cover government expenditures. It follows directly from the fact that the Polish people have actually hitherto borne out of their current income the ordinary expenditures of government, and have done so during a time when those expenditures were relatively higher and the income of the people relatively lower than at present. The fundamental thing which must never be overlooked is that, apart from the using up of past savings or from borrowings abroad, a country has nothing with which to support its government except its current production and the current income of its people. Paper money creates nothing.
It is merely a means of transferring part of the income of the people to the coffers of the government. You may call it a forced loan or call it a tax; in either case it comes out of the pockets of the people. The process of extraction through paper-money inflation may be easier than by other forms of taxation, but with sufficiently vigorous government and sufficient patriotism and good sense on the part of the people, other forms of taxes can be substituted for the paper-money tax.

As a matter of fact, if you calculate the burden of the Polish budget for 1922 in terms of sound money-not even using exchange rates as a basis, but rather the internal buying power of money as compared with pre-war times -you will find that it amounts to not more than $\$ 200,000,000$, or say $\$ 7.50$ per capita of the Polish population. This is gross; the net expenditures are only two-thirds as much. Our national taxes are six times as much per capita. The chief reason why the burden in Poland is comparatively low is because Poland has, for present practical purposes, a very small internal interest-bearing debt. To be sure, the debt reads, in terms of paper money, many billions of marks (30 billions apart from paper money) but the interest on it has to be paid only in the terms of marks worth not much more than one-thousandth of their par value. When the average wage earner who before the War received 3 marks per day now gets 1,500 to 2,500 , government expenditures of hundreds of billions cease to look so appalling.

\section{Future Reckoning}

But how about the future? Must there not come a day of reckoning when these billions of internal bonds, these scores of billions of paper notes, must be paid in sound money? Has not the Polish government laid up a 
crushing burden for generations to come?

I do not care to pose either as a prophet or as a counsellor, and I, therefore, do not propose to answer these questions. It is pretty obvious that the currency of many of the European countries can never be brought back to par. The combined face value of European currencies, not counting the astronomical figures of Russian roubles, runs far over a hundred billions of dollars, or many times the total gold stock in all the world. Whether it is possible, or, if possible, desirable, for countries like Poland to attempt to increase materially the value of their paper money, without attempting to bring it all the way back to par, is a question concerning which much may be said on both sides.

This much is certain:

The first step towards sanitation of the currency is to stop further printing of it. Practically the only means by which this can be accomplished, in the case of most European countries, is by balancing the budget through internal effort, by making current receipts of the government from its own people equal to its current expenditures. There is little prospect that the United States or other countries with sound or approximately sound currency will make great loans to countries with depreciated currency for the purpose of stopping depreciation; they may make such loans after the process of depreciation has ceased. No country ought to ask the people of another country to lend it money to cover current costs of government, and if it does ask it, the answer is pretty sure to be disappointing. Only when once the people of a country have shown themselves able and willing to pay as they go, may they hope to borrow money to clear up old debts, to provide new capital investments, or to put a metal basis under their currency.

And, secondly, it is more important for the reëstablishment of normal economic conditions in Eastern Europe that foreign capital should be invested there in productive industry than that it should be loaned to governments to cover current deficits, or be used in the attempt to introduce prematurely a sound currency system before the budget is balanced by internal revenues. Industry can make progress despite the unsatisfactory currency situation but it needs new capital to replace that lost during the War. With the increased production which new capital would bring about, these countries will be in a better position to balance their budgets and to place their currency on a sound footing. 